\title{
СТАВОВИ НА РОДИТЕЛИТЕ НА ДЕЦА СО ИНТЕЛЕКТУАЛНА ПОПРЕЧЕНОСТ И СТРУЧНИ ЛИЦА КОИ РАБОТАТ СО НИВ ПО ОДНОС НА СЕКСУАЛНО ВОСПИТАНИЕ
}

\section{Кратка содржина}

Ставовите по прашањето на сексуалноста на лицата со интелектуална попреченост многу бавно и малку се менуваат. Сексуалноста на овие лича е табу тема и во дневните центри каде се одвива нивниот третман, но и во нивните семејства. Истражувањето имаше за чел да утврди дали вработените во дневните центри во Куманово, Велес, Битола и Крива Паланка се подготвени за реализауија на активности од подрачјето на сексуалното воспитание. Со истражувањето беа опфатени 64 родители на деца со умерена и тешка интелектуална попреченост и 19 лича вработени во дневните чентри кои директно се вклучени во нивниот третман. И двете групи испитаници сметаат дека активностите од областа на сексуалното воспитание треба да се применуваат, но како предуслов треба и вработените во дневните центри и родителите да поминат обуки за нивна примена. Како дополнителен проблем е недостатокот на нагледни средства за реализачија на овие активности.

Клучни зборови: СТАВОВИ, ДЕЦА СО ИНТЕЛЕКТУАЛНА ПОПРЕЧЕНОСТ, ВРАБОТЕНИ ВО ДНЕВНИ ЦЕНТРИ, РОДИТЕЛИ, СЕКСУАЛНО ВОСПИТАНИЕ

Денес лицата со попреченост постепено го заземаат заслуженото место во општеството како еднакви со лицата без попреченост. За жал, во однос на сексуалноста и попреченоста, општествените ставови многу малку се променети. Дури и денес, многу луѓе одбиваат да признаат дека сите индивидуи имаат сексуални чувства, потреби и желби, без разлика на нивните физички и/или ментални способности. Како резултат на тоа, многу млади лица кои имаат попреченост, не добиваат сексуално образование, ниту во училиштата, ниту во сопствените домови (Ајдински, Каровска Ристовска, 2014).

Лицата со попреченост имаат различно потекло, доаѓаат од различни заедници, со свои културни и религиозни верувања кои постојат во нашето општество. За да им се овозможи да донесуваат правилни одлуки и избори за врските и сексуалните односи, важно е да се почитува поширокиот контекс на животот на поединецот, вклучувајќи ги вредностите и ставовите на неговото семејство и заедницата. Однесувањето и изборот на лицето со попреченост, доколку не е во согласност со вредностите и ставовите на неговите родители/старатели, може значај- 
но да влијае на односите со семејството, пријателите и заедницата. Од голема важност е стручните лица/вработените да бидат свесни за различните ставови што ги имаат родителите/старателите. Родителите/старателите треба да имаат можност да учествуваат во планирањето на пристапи до образование и поддршка на лицата со попреченост во однос на врските и сексуалноста.

Младите лица со интелектуална попреченост можеби не се способни да добијат пристап до специфични информации достапни на нивните врсници без интелектуална попреченост, заради тешкотии во писменоста, когнитивни тешкотии или бидејќи се потпираат врз други да им помогнат да дојдат до тие информации. Затоа, може да биде тешко да се заклучи што едно младо лице со интелектуална попреченост знае или би сакало да знае. Од голем број публикувани материјали добиваме некаква претстава за оценувањето на знаењето и разбирањето на младите лица со интелектуална попреченост за сексуалноста, односно за нивното сексуално образование.

Истражувањата на Младеновска и Трајковски (2010) укажуваат дека во Р. Македонија во рамките на семејствата и во училиштата постои многу мал степен или воопшто не постои комуникација и разговор помеѓу родителите и стручните кадри со лицата со аутизам на тема сексуален развој, однесување и полов идентитет. Лицата со аутизам немаат никакви познавања за сексуалноста. Лицата со инвалидност своите знаења за половиот развој, карактеристики и полови односи ги стекнуваат најмногу преку медиумите и разговор со своите врсници (Рашиќ и Трајковски, 2009). Овие автори укажуваат на фактот дека во рамките на семејствата може да се каже дека само во мала количина се спроведува полово воспитание, $40 \%$ од родителите се изјасниле дека на таа тематика разговараат само доколку детето нешто ги праша, а 20\% и воопшто не зборуваат на таа тема. $50 \%$ родители не провериле што знаат нивните деца за половото однесување и карактеристиките на развојот, а 36,67\% родители одговориле дека им е непријатно да разговараат на таа тема со своите деца. Токму во таа смисла се укажува на потребата од посебна едукација на дефектолозите, останатиот стручен кадар и родителите на лицата со инвалидност во однос на половата едукација, превенцијата и навременото откривање на сексуалната злоупотреба на оваа категорија на лица (Рашиќ, 2009).

Сексуалната едукација би требало да овозможи стекнување на здрави сексуални навики, но и подигнување на нивото на самодоверба и превенција во сексуалната експлоатација на овие лица (Koller, 2000). Во услови на тековните процеси на деинституционализација и инклузија во пошироката општествена заедница, формалната сексуална едукација претставува важен предуслов за подигнување на квалитетот на животот на лицата со аутизам односно на лицата со пречки во развојот (Banković, Đorđević, 2012).

Во Република Македонија едукацијата за сексуалното и репродуктивното здравје кај лицата со попреченост и нивните семејства е сѐ уште табу тема и поради тоа, потребно е систематско воведување на целосно и научно втемелено едуцирање во основните и средни училишта коишто ги посетуваат лицата со попреченост, како и во дневните центри, како и интензивна едукација на нивните родите- 
ли/старатели, со цел тие да бидат оспособени за справување со предизвиците коишто ги имаат на оваа тема (Петров и Лазова-Здравковска, 2014).

\section{Сексуално воспитание}

Во образовниот систем е занемарено сексуалното воспитание и образование. Не постои посебен наставен предмет, адаптиран според возраста, кој ќе нуди релевантни сознанија за позитивните аспекти на сексуалноста, и за сексуалното и репродуктивното здравје. Увидот во постојните наставни предмети покажува дека информациите дадени во различни предмети, се оскудни, недоволни, стереотипизирани и со негативни ставови кон љубовта и сексуалноста (ХЕРА, 2010). Наставниците пак, исто така под влијание на личните предрасуди и стереотипи, а најмногу поради недостатокот на систематска едукација за време на стекнувањето на професионалните компетенции, не се чувствуваат подготвени да предаваат и отворено да разговараат за сите аспекти на сексуалноста, ниту пак ги препознаваат аспектите на сексуалната приватност на учениците (само 5,6\% наставници изјавиле дека можат да зборуваат за контрацепција и за менструација, само $2,8 \%$ можат да зборуваат за пол и род, и исто толкав процент од 2,8\% наставници можат да зборуваат за сексуална ориентација) (ХЕРА, 2010).

\section{Дефиниции за сексуално воспитание на УНЕСКО и МФПР}

„Сексуалното воспитание се дефинира како соодветен за возраста пристап кон информирањето за сексот и врските, преку обезбедување на научно точни, реалистични и не осудувачки информации. Сексуалното воспитание нуди можности да се истражат сопствените вредности и ставови и да се изградат вештини за донесување одлуки, комуникација и намалување на ризикот во врска со многу аспекти на сексуалноста" (UNESCO, 2009; 2).

„Сеопфатното сексуално воспитание има за цел да ги обезбеди младите луѓе со знаење, вештини, ставови и вредности, потребни да одлучуваат и уживаат во нивната сексуалност - физички и емоционално, индивидуално и во врските. Дава холистички поглед на сексуалноста во контекст на емоционалниот и социјалниот развој. Признава дека информациите сами по себе не се доволни. Младите треба да имаат можност да се стекнат со основни животни вештини и да развијат позитивни ставови и вреднсоти““ (IPPF, 2010:6).

\section{Целта на сексуалното воспитание}

Целта на сексуалното воспитание е да ги упати децата и младите во промените поврзани со нивниот развој, да им помогне да ги разберат позитивните аспекти на сексуалноста, односно да развијат позитивни ставови и вредности за сексуалноста, и да ги оспособи да донесуваат информирани и правилни одлуки за својот сексуален живот и сексуалното здравје, како и за врските и односите со другите луѓe. За таа цел, сексуалното воспитание треба да обезбеди навремени и проверени информации за сексуалноста, сексуалното и репродуктивното задравје, а во согласност со возраста и потребите на младата популација (Симоновска, 2014). 


\section{Ефекти и придобивки од сексуалното воспитание}

Спроведените истражувања и анализи покажуваат дека освен зголеменото ниво на знаење, тоа придонесува и за:

- Одложување на започнувањето со сексуална активност или намалување на бројот на сексуални партнери

○ Зголемување на употребата на контрацепцијата и кондом кај сексуално активните адолесценти

○ Поодговорно сексуално однесување и понатаму во животот

○ Унапредување на нивното сексуално и репродуктивно здравје, и здравјето во целост

- Зголемување на способноста за носење на правилни одлуки и намалување на предрасудите

○ Развивање на позитивни ставови и вреднсти за сексуалноста

Може да се заклучи дека едно сеопфатно сексуално воспитание, освен што придонесува во заштитата на сексуалното и репродуктивното здравје на младите луѓ, тоа има голема улога и во нивното развивање како одговорни, но и толерантни личности кои ќе ги почитуваат потребите и правата на другите. Затоа, придобивките од сексуалното воспитание, не се само придобивки за поединците, туку и за целото општество. Сето тоа води кон унапредување на човековите права, што пак придонесува кон постигнување на добросостојбата за сите, и за поединците и за општеството (XЕРА, 2010б).

\section{Карактеристики на сексуалното однесување на лицата со пречки во ментал- ниот развој}

Лицата со интелектуална попреченост ги карактеризираат различни пречки во развојот со различен степен и различно варирање. Пречките, некогаш може веднаш по раѓањето да се воочат, но понекогаш истите се воочуваат подоцна, а тоа пак би значело дека самиот развој на личноста е дисхармоничен и несоодветен за негова возраст. Лицата со тешка интелектуална попреченост по клиничка слика се слични како и лицата со умерена интелектуална попреченост. Разликата е очигледна во значително ограничените способности во областа на говорот, јазикот, моторните способности и грижата за себе. Поголем број на лица од оваа категорија имаат изразени моторни и други придружни оштетувања кои укажуваат на оштетување или пореметување во развојот на централниот нервен систем. На стандардизираните тестови, IQ-то се движи од 20-34. Лицата со длабока интелектуална попреченост се најтешката категорија која се карактеризира со ограничени способности за разбирање и прифаќње на барањата или упатствата. Кај овие лица присутни се само рудиментирани форми на невербална комуникација. Поголем број од овие лица се полуподвижни или неподвижни и немаат способност да ги контролираат своите физиолошки потреби. Овие лица не се способни сами да се грижат за себе, поради тоа имаат потреба од постојана помош, нега и надзор од друго лице. На стандардизираните тестови IQ-то им е под 20 (Ајдински, 2014). 


\section{Нивото на информираност кај лицата со интелектуална попреченост}

Се претпоставува дека големо влијание врз сексуалното однесување кај лицата со интелектуална попреченост има и нивното ниско ниво на познавање на различни прашања и теми кои се поврзани со сексуалноста. Како најчеста причина се наведува недоволното познавање на телото и сликата за себе, посебно недоволното познавање на интимните делови од сопственото тело. Во глобала, голем дел од лицата можат да распознаат машко од женско, но истите имаат потешкотии во прецизното одредување на сличностите или разликите меѓу половите. Спротивно од ова, некои лица со интелектуална попреченост знаат да ги идентификуваат деловите од сопственото тело, но истите немаат доволни познавања за тоа каква е функцијата на тие делови. Според тоа кои лица имаат поголемо ниво на информираност, дали оние кои се сместени во институцијата или пак оние кои се интегрирани во средината, заклучено е дека најголем степен на знаења поврзани со сексуалноста и сексулниот живот имаат адолесцентите кои не се сместени во институцијата. И кај едните и кај другите, забележано е одредено ниво на познавања поврзани со мастурбацијата, сексуалните односи, менструацијата и бременоста, но истите немаат доволно познавања кои се поврзани со полово преносливите болести и со контролирањето и заштитата од бременост. Тука се опфаќаат и социјалните ставови и мислења на двете групи, па така според социјалното функционирање се бележат и разлики во бројот на сексуалните искуства. Според ова, поголем број на искуства имаат неинституционализираните лица, а институционализираните лица се покажале подобри во: запознавањата или таканаречениот „dating“, околу сексуалните односи, околу контролата за раѓање (Младеновиќ, 2014).

\section{Методологија на истражување}

Предмет на ова истражување се ставовите кои ги имаат вработените во дневните центри во Куманово, Битола, Велес и Крива Паланка, како и родителите на нивните корисници, за примената на активностите од областа на сексуалното воспитание.

Истражувањето има за цел да се утврди дали вработените од дневните центри и родителите на децата кои се опфатени со третман во нив се подготвени за реализација на активностите од областа на сексуалното воспитание.

Во текот на истражувањето користени се метод на анализа на содржина и анкетирање. За потребите на истражувањето конструиран е анкетен прашалник со 20 прашања за процена на ставови со тристепена скала од Ликертов тип, каде 1 означува воопшто не се согласувам, 2 означува делумно се согласувам и 3 означува потполно се согласувам. Прашалникот е применет кај двете групи испитаници, вработени во дневните центри и родителите на децата корисници на дневните центри.

Податоците добиени со истражувањето се обработени со помош на статистичката програма SPSS (Statistical Package for Social Sciencess). 
За да се потврдат/отфрлат поставените хипотези потребно беше да се пресмета $\mathrm{t}-$ тест, со што се утврди значајноста на разликата помеѓу две споредувани групи.

Со цел да се испита дали постои разлика помеѓу ставовите на сите групи применивме AНОВА за значајноста на разликите помеѓу сите споредувани групи.

\section{Резултати од истражувањето}

Родителите на децата со умерена и тешка интелектуална попреченост имаат попозитивен став по прашање на примена на активности од подрачјето на сексуално воспитание.

Табела 1. Значајност на разлики на ставот во однос на улогата на испитаниците

\begin{tabular}{|c|c|c|c|c|c|}
\hline \multirow{3}{*}{ Сексуалност } & Улога & $\mathrm{N}$ & $\begin{array}{c}\text { Средна } \\
\text { вредност }\end{array}$ & $\mathrm{T}$ & $\mathrm{P}$ \\
\cline { 2 - 6 } & Родители & 64 & $\begin{array}{c}32,0625 \\
30,052\end{array}$ & 1,112 & $>0,05$ \\
\hline
\end{tabular}

Податоците од истражувањето покажуваат дека нивото на образование на вработените не влијае на ставот.

Табела 2. Значајност на разлики според образовниот статус на испитаниците

\begin{tabular}{|c|c|c|c|c|c|}
\hline \multirow{3}{*}{ Сексуалност } & Образ.статус & $\mathrm{N}$ & $\begin{array}{c}\text { Средна } \\
\text { вредност }\end{array}$ & $\mathrm{T}$ & $\mathrm{P}$ \\
\cline { 2 - 6 } & Средно & 7 & 28,7143 & & \\
& Високо & 12 & 30,8333 &,- 513 & $>0,05$ \\
\hline
\end{tabular}

Следната табела покажува дека степенот на интелектуална попреченост не влијае кај родителите за прифаќање или не на активностите од областа на сексуално воспитание. И родителите на деца со умерена и оние со тешка подеднакво ги перцепираат овие активности.

Табела 3. Значајност на разлики според степенот на интелектуалната на децата

\begin{tabular}{|c|c|c|c|c|c|}
\hline \multirow{2}{*}{ Сексуалност } & $\begin{array}{c}\text { Степен на } \\
\text { попреченост }\end{array}$ & $\mathrm{N}$ & $\begin{array}{c}\text { Средна } \\
\text { вредност }\end{array}$ & $\mathrm{T}$ & $\mathrm{P}$ \\
\cline { 2 - 6 } & Умерена & 50 & 31,5200 & & \\
& Тешка & 12 & 34,0000 & $-1,143$ & $>0,05+$ \\
\hline
\end{tabular}


Возраста на децата не дава повторно статистички значајна разлика, иако очекувавме дека родителите на деца на поголема возраст ќе искажуваат поголема потреба од реализација на ваквите активности.

Табела 4. Значајност на разликите помеѓу ставот на родителите на деца од различна возраст

\begin{tabular}{|c|c|c|c|c|c|}
\hline Сексуалност & $\begin{array}{c}\text { Сума на } \\
\text { квадрати }\end{array}$ & Df & $\begin{array}{c}\text { Среден } \\
\text { квадрат }\end{array}$ & F & Sig. \\
\hline Помеѓу групи. & 198,483 & 3 & 66,161 & &, 217 \\
Во групите & 2601,267 & 60 & 43,354 & 1,526 &, 267 Вкупно \\
2799,750 & 63 & & & \\
\hline
\end{tabular}

И должината на третманот на децата во дневниот центар не влијае на ставот на родителите.

Табела 5. Значајност на разлики помеѓу деца со различна должина на третман

\begin{tabular}{|c|c|c|c|c|c|}
\hline & Возраст & $\mathrm{N}$ & $\begin{array}{c}\text { Средна } \\
\text { вредност }\end{array}$ & $\mathrm{T}$ & $\mathrm{P}$ \\
\cline { 2 - 6 } Сексуалност & До 5 години & 12 & 33,8333 & & \\
& $6-10$ години & 52 & 31,6538 & 1,021 & $>0,05$ \\
\hline
\end{tabular}

Ставот е различен во различните градови. Очекувавме дека срединскиот фактор ќе игра улога во градењето на ставот, но и културниот контекст, верската и етничката припадност. Податоците покажуваат дека најпозитивен став имаат родителите на децата од Куманово, а најнегативен оние од Велес.

Табела 6. Разлики во ставот за сексуалност по градови

\begin{tabular}{|c|c|c|c|}
\hline Дневен центар & Средна вредност & $\mathrm{N}$ & $\begin{array}{l}\text { Стандардно } \\
\text { отстапување }\end{array}$ \\
\hline Куманово & 43,0000 & 2 & 1,41421 \\
\hline Битола & 34,0000 & 4 & 3,46410 \\
\hline Велес & 21,7500 & 8 & 2,65922 \\
\hline Крива Паланка & 35,0000 & 5 & 5,95819 \\
\hline Вкупно & 30,0526 & 19 & 8,50146 \\
\hline
\end{tabular}


Со определување на аритметичка средина на секое од прашањата понудени во прашалникот за процена на ставови за сексуалноста и сексуалното воспитание на деца со умерена и тешка интелектуална попреченост. Можеме да забележиме дека родителите во најголем број сметаат дека вработените во дневните центри се доволно запознаени и обучени за примена на активности од областа на сексуалното воспитание, како и дека децата со умерена и тешка интелектуална попреченост умеат да ги искажат своите емоции.

Наспроти ова податоците велат дека децата со умерена и тешка интелектуална попреченост знаат како да препознаат сексуална злоупотреба. Исто така во голем број сметаат дека не е точен исказот дека родителите на децата со умерена и тешка интелектуална попреченост имаат многу високи очекувања во врска со сексуалниот живот на нивните деца.

Можеме да издвоиме два исказа кои се издвојуваат и каде вработените сметаат дека децата имаат најголем успех. Тие велат дека децата со умерена и тешка интелектуална попреченост умеат да ги искажат своите емоции и дека децата со умерена и тешка интелектуална попреченост можат да препознаат што значат убави чувства.

Загрижува фактот дека најмалку познавања имаат за некои содржини кои не бараат дополнителна едукација или нагледни средства. Најмалку од нив велат дека децата со умерена и тешка интелектуална попреченост имаат реална слика за себе и своето тело.

Понатаму децата со умерена и тешка интелектуална попреченост имаат познавања за репродукција и планирање на семејството. Децата со умерена и тешка интелектуална попреченост знаат да го контролираат сексуалниот нагон, како и дека децата со умерена и тешка интелектуална попреченост знаат како да се заштитат од полово преносливи болести Децата со умерена и тешка интелектуална попреченост имаат претстава како се родени и децата со умерена и тешка интелектуална попреченост знаат како да препознаат сексуална злоупотреба

\section{Заклучоци:}

Многу беше значајно и искуството на личен контакт со родителите, каде може да се слушнат реално ставовите за прашањата кои ги проучувавме и што си ги поставивме како задача за проучување во нашето истражување.

Врз основа на поставените цели и задачи и со извршената анализа на резултатите од истражувањето добиени од анкетните прашалници, како и земајќ ги во предвид дискусиите со родителите и вработените во дневните центри, можеме да ги изведеме следниве заклучоци:

Родителите на децата имаат попозитивен став во однос на тимот кој работи со нивните деца.

Работниот стаж и искуството на работа со оваа категорија деца не игра улога во прифаќањето на активностите од областа на сексуалното воспитание. 
Резултатите од квантитативната анализа покажуваат дека полот на децата, нивната возраст и времето на третман во дневниот центар статистички значајно не влијаат на ставот кон проблемот кој го проучуваме.

Интересен е фактот до кој дојдовме со непосреден контакт со родителите дека родителите на децата албанци имаат многу позитивен став по однос на сексуалното воспитание, сексуалноста, дури отвотено дискутираат за плановите за нивно потомство и брак на децата, за разлика од родителите на децата од македонска националност. Спротивно на ова вработените од албанска националност помалку сакаат да разговараат на оваа тема и помалку ги прифаќаат активностите од оваа подрачје во однос на нивните колеги македонци.

Родителите имаа можност да дадат свое размислување и дополнување на прашањата на крајот од анкетниот прашалник па така родител на дете со умерена интелектуална попреченост од Битола сепак вели дека „сексуалноста е табу тема, многу е тешко да им се објасни на децата, а уште потешко да разберат“.

Друг родител на дете со умерена интелектуална попреченост од Битола вели: „Децата со попреченост во развојот не се свесни за својата сексуалност, ниту пак се способни за брак. Со умерена попреченост може да имаат свое мислење и можат да работат. Проблемите со кои се соочуваме се: финансиски, здравствена нега“.

Родителите од Куманово велат дека е потребно организирање семинари и обуки за нив. Дел од родителите напишале дека вработените треба да се обучат дополнително. Дел од родителите на женски деца сметаат дека треба да им се обезбедат редовни гинеколошки прегледи на нивните деца. Тројца од родителите напишале дека треба да се искористат позитивни искуства од странство но и вработените да одат на обука во држави кои имаат добро искуство со грижата за сексуалното здравје на лицата со интелектуална попреченост.

Сите вработени во дневниот центар од Куманово велат дека родителите треба да бидат информирани како да се грижат за сексуалното здравје на своите деца. Велат дека треба да се организираат семинари и обуки за родители. Еден од вработените навел дека е потребна едукација и на вработените. Тоа е тоа што е ставено во прашалниците а сите до еден усно велат дека им е потребна дополнителна едукација. Од Министерство за труд и социјална политика и Завод за социјални дејности (кој е надлежен за нивната доедукација) им е ветена обука од невладината организација XЕPA, но таа едукација сѐ уште не е реализирана. Исто така укажуваат и од потребата од набавка на нагледни средства и едукативни материјали.

Бројни истражувачи се занимавале со сексуалноста, сексуалното воспитание и образование на лицата со инвалидност, како и општествениот став по ова прашање.

Меѓуународни истражувачки докази укажуваат на тоа дека лицата со интелектуална попреченост имаат лошо знаење за сексуалното здравје (Cheng and Udry, 2003; Galea et al., 2004; Lesseliers and Van Hove, 2002; Szollas and McCabe 1995). 
Се чини дека според вештините и информираноста на лицата со интелектуална попреченост, тие имаат потреба да живеат во заедница, но промените не се одвиваат во чекор со менување на општествените ставови отелотворени во деинституционализацијата (Szollas и McCabe 1995).

Важна бариера со која се соочуваат лицата со интелектуална попреченост е во формирањето на односите се ставовите на луѓето што живеат со нив и ставовите на вработените кои ги поддржуваат (Abbott \& Howarth 2005). Во обезбедувањето на лица со „заштитувана” животната средина, многу родители /старатели им дозволуваат пристап до можности за формирање на односите (Abbott \& Howarth 2005).

Лицата со интелектуална попреченост често се соочуваат со предрасуди и малтретирање во нивниот секојдневен живот (Abbott \& Howarth 2005).

Во една австралиска студија, Меккејб (МcСabe 1999) го истражувал сексуалното здравје, искуство, чувствата и потребите на лицата со интелектуална и телесна попреченост и направена е споредба на нивните потреби и искуства во однос со општата популација. Во истражувањето беа вклучени 60 возрасни лица со лесна интелектуална попреченост, 60 возрасни лица со физичка попреченост и 100 возрасни од општата популација. Меккејб покажа дека само 50\% од испитаниците со инвалидитет добиле некоја форма на сексуално образование, во споредба со над $80 \%$ од општата популација. Студијата покажала дека дури и таму каде било обезбедено сексуално воспитание за сексуалното здравје, бил потребен поголем напор за да се подобри сексуалното здравје на лицата со попреченост.

Големи празнини се идентификувани кај лица со интелектуална попреченост во врска со знаењето за побезбедни сексуални односи. Истражувањето покажало дека нивото на знаење за сексуалното здравје е пониско за луѓето со потешкотии во учењето, отколку за лица со физички пречки во развојот, кои за возврат беа, пониски отколку кај општата популација. Информациите и едукацијата во областа на сексуалноста во општата популација се составен дел од животот на родителите и пријателите, како и неформалното образование. Студијата заклучува дека испитаниците инвалиди имаат силна потреба да се состануваат, имаат потреба од интимна и сексуална интеракција, но поради недостаток на знаење, нивните негативни чувства во врска со сексуалноста и можеби нивниот недостаток на можност за сексуално изразување, тие во моментов не можат да се вклучат во овие искуства (McCabe, 1999).

Ова укажува на фактот дека има помалку дискусии за сексуалните прашања во семејството и пријателите, меѓу испитаниците со посебни потреби, кои за возврат можат да пренесат и негативни пораки од оние со сегашниот статус на сексуално воспитание (Allen \& Seery, 2007).

Во една студија во Ирска, Еванс покажал дека еден од пет испитаници од персоналот (20\%) немал доверба во нивната способност да разговараат за прашања од сексуалноста и скоро сите (95\%) вработени изјавиле дека би биле заинтересиран за добивање обука за сексуално воспитание (Evans, 2002) 
Слични наоди биле објавени од страна на Ален кој ги истражувал услугите на корисниците, вработените и негувателите од NTDIво Ирска. Истражувањата покажале дека две третини (62\%) од испитаниците вработени и негуватели, разговарале за здравствените и сексуалните проблеми. Сепак, прашањата главно се занимавале со бременоста и менструацијата. Овој кадар е опишан како кадар со ниско ниво на доверба во однос на дискутирање на сексуалните прашања. Сите три групи на испитаници изразиле силна желба да се вклучат во обука за поддршка на испорака на сексуално и репродуктивно здравје за лица со интелектуална попреченост (Allen, 2004).

Австралискиот модел за вработените кои работат со лица со попреченост во областа на репродуктивно и сексуално здравје што е наведен од страна на Чиверс и Матисон, покажал дека иако вработените морале да реализираат обуки на лицата со инвалидност сметајќи се доволно подготвени за оваа област продолжуваат да ја користат како „експерти“ за обука со корисниците на услуги (Chivers \& Mathieson, 2000).

Тие укажуваат на тоа дека доминантна дискусија во рамките на организацијата во однос сексуално и репродуктивно здравје била биолошка. Најчести содржини на курсот биле сексуално преносливите инфекции, бременоста и контрацепцијата со кои се става акцент на опасност и ризик. Така поставените цели за учењето и истражувањето на сопствената сексуалнот, развивањето пријателства и потребата за интимност, не се зеле во предвид.

Кемптон и Кан препорачуваат во општото образование за сексуалното здравје да се вклучат повеќе основни информации за контрацепцијата и механизмите на сексот, а исто така и теми за телото и комуникациските вештини и сл. кои доведуваат до поголемо знаење и промени во однесувањето на лицата со интелектуална попреченост за краток или долг временски период (Kempton\&Kahn, 1991).

\section{Препораки}

$>$ Доедукација и организирање обуки на вработените од дневните центри по прашањето на сексуалното воспитание и здравствената заштита на нивните корисници.

$>$ Користење на капацитетот на невладини организации кои се занимаваат со оваа проблематика.

> Следење на меѓународните искуства од областа на сексуалноста и сексуалното воспитание и образование на лицата со инвалидност, разгледуваве добри практики и разгледување на можноста за нивна инплементација во македонски услови

$>$ Организирање заеднички средби, обуки и семинари со родителите на децата со интелектуална попреченост.

$>$ Набавка на нагледни средства, материјали и снимки кои се однесуваат на здравствената заштита, полово преносливите болести, можностите на сексуална злоупотреба, искажување емоции, пријатни чувства и мастурбирање. 
$>$ Организирање редовни и задолжителни гинеколошки прегледи на повозрасните корисници.

$>$ Едукација на семејствата по прашање на законската легислатива, но и реалните можности и способности на нивните деца по прашања на брак и семејство.

$>$ Едукација на родителите за правата и обврските на нивните деца.

$>$ Користење на мас медиумите за подигање на јавната свест за заштита од сексуална злоупотреби на лицата со интелектуална попреченост. 


\section{Литература}

Ајдински, Г., Каровска Ристовска, А. (2014). Сексуално образование на лица со интелектуална попреченост. Аспекти на сексуалност и сексуално образование. Збир на текстови. Филозофски факултет Скопје, ХЕРА (Асоцијација за здравствена едукација и истражување) Скопје, 36-43.

Младеновска, Б., Трајковски В. (2010). Ставовите и мислењата на родителите и студентите за сексуалниот развој, однесување и полов идентитет кај лицата со аутизам во Република Македонија UDK: 159.922.1.07:616.89(497.7).

Петров, Р., Лазова-Здравковска, С. (2014). Сексуалното и репродуктивното здравје на лицата со попреченост. ISBN 978-608-4598-04-6

Рашиќ, О. (2009). Полов развој, воспитание и сексуална злоупотреба на лицата со инвалидност во Република Македонија. UDK: 376.24:176.4(497.7).

Рашиќ, О., Трајковски, В. (2009). Полова едукација на лицата со инвалидност. Филозоски факултет, Институт за дефектологија, UDK. 37-055-056.24.

Симоновска, С. (2014). Концепт на сеопфатно сексуално образование . Аспекти на сексуалност и сексуално образование : збир на текстови.- Скопје : Хеpa, 2014. 9-10 стр.

Симоновска, С., Кениг, Н., Спасовски, О., Ајдински, Г., Каровска Ристовска, А., Тим за подршка на ХЕРА-Костовски, Д., Матевска, В. (2014). Аспекти на сексуалност и сексуално образование : збир на текстови.- Скопје : Хера, 2014. - 48 стр.

ХЕРА, 2010а. Љубов само по часови: проченка на потребата и на достапноста на информациите од областа на сексуалното образование во Македонија. Скопје: ХЕРА

XEPA, 2010 б. Рамка за сеопфатно сексуално образование. Скопје: XEPA. 
Natasha STANOJKOVSKA-TRAJKOVSKA

\section{VIEWS OF PARENTS OF CHILDREN WITH INTELLECTUAL \\ DISABILITY AND PROFESSIONALS THAT WORK WITH \\ THEM IN RESPECT OF SEXUAL EDUCATION}

\section{Summary}

The views on the issue of sexuality of people with intellectual disability are very slowly and slightly changing. Sexuality of these people is taboo in both, day centers where they place their treatment, and their families. The survey was designed to determine whether employees in day care centers in Kumanovo, Veles, Bitola and Kriva Palanka are prepared for implementation of activities from the area of sexual education. The survey covered 64 parents of children with moderate and severe intellectual disabilities and 19 persons employed in centers that are directly involved in their treatment. Both groups of respondents believe that the actions in the field of sexual education should be applied, but as a precondition employees in day care centers and parents should receive training on their application. Additional problem is the lack of teaching aids for the implementation of these activities.

Keywords: VIEWS, CHILDREN WITH INTELLECTUAL DISABILITIES, EMPLOYEES IN DAY CARE CENTERS, PARENTS, SEX EDUCATION 